\title{
PENGARUH IMPLEMENTASI MANAJEMEN KELAS TERHADAP PERILAKU BELAJAR MAHASISWA PADA JURUSAN MANAJEMEN PENDIDIKAN ISLAM FAKULTAS TARBIYAH DAN KEGURUAN UIN ALAUDDIN MAKASSAR
}

\author{
Ahmad Afiif \\ Fakultas Tarbiyah dan Keguruan UIN Alauddin Makassar \\ Kampus II: Jalan Sultan Alauddin Nomor 36 Samata-Gowa \\ Email: ahmadafiif@ymail.com \\ Ridwan Idris \\ Fakultas Tarbiyah dan Keguruan UIN Alauddin Makassar \\ Kampus II: Jalan Sultan Alauddin Nomor 36 Samata-Gowa \\ Email: ridwanidris34@gmail.com
}

\begin{abstract}
Abstrak:
Artikel ini memuat hasil penelitian yang bertujuan untuk mengetahui pengaruh implementasi manajemen kelas terhadap perilaku belajar mahasiswa Jurusan Manajemen Pendidikan Islam Fakultas Tarbiyah dan Keguruan UIN Alauddin Makassar. Pendekatan penelitian kuantitatif dengan jenis penelitian Ex Post Facto dan model penelitian penelitian deskriptif korelasional. Populasi dalam penelitian ini adalah seluruh mahasiswa Jurusan Manajemen Pendidikan Islam Fakultas Tarbiyah dan Keguruan. Sampel penelitian berjumlah 31 mahasiswa. Adapun metode yang digunakan dalam pengumpulan data adalah angket implementasi manajemen kelas dan skala perilaku belajar. Teknik analisis data yang digunakan adalah menggunakan rumus regresi linear sederhana. Hasil penelitian menunjukkan bahwa terdapat pengaruh positif antara implementasi manajemen kelas dan perilaku belejar dimana $\boldsymbol{r}_{\text {hitung }}=0,68>r_{\text {tabel }}=0,367$. Ini berarti makin baik implementasi manajemen kelas maka makin baik pula perilaku belahar mahasiswa.
\end{abstract}

\begin{abstract}
:
This paper contains the results of the research which aimed to determine the effect of the implementation of classroom management on students learning behavior at the Department of Islamic Education Management at Tarbiyah and Teaching Faculty of UIN Alauddin Makassar. The research approach was quantitative with the type of Ex Post Facto and the model of research was descriptive correlational study. The population of the research was all of the students of the Department of Islamic Education Management of Tarbiyah and Teaching Faculty. The sample consisted of 31 students. The methods that were used in the data collection was a questionnaire on the implementation of classroom management and a scale of learning behavior. Data analysis techniques used was simple linear regression formula. The results of the research pointed-out that there was a positive correlation between the implementation of classroom management and students learning behavior. This means that the better the implementation of class management, the better the student learning behavior.
\end{abstract}

Kata kunci:

Pendidikan, epistemologi, dikotomi, pembaruan

SALAH satu unsur yang tidak dapat dipisahkan dari kehidupan manusia adalah pendidikan. Pendidikan diperoleh manusia melalui orang tua, masyarakat, dan ling-

PENGARUH IMPLEMENTASI MANAJEMEN KELAS (AHMAD AFIIF DAN RIDWAN IDRIS) 
kungan yang ada disekitarnya. Pendidikan merupakan aktivitas yang berlangsung sepanjang hidup manusia. Pendidikan pada hakekatnya merupakan proses pendewasaan manusia untuk menjadi pribadi yang bijaksana. Pendidikan dapat dikatakan sebagai penolong dalam menjalani kehidupan yang terus berkembang. Tanpa pendidikan manusia tidak akan maju dan takkan mampu untuk melakukan perubahan-perubahan sesuai dengan perkembangan zaman. Pendidikan merupakan wahana untuk meningkatkan dan mengembangkan kualitas sumber daya manusia, oleh karena itu pendidikan memiliki andil yang sangat besar dalam perkembangan suatu bangsa.

Menurut Undang Undang Republik Indonesia Nomor 20 tahun 2003 tentang Sistem Pendidikan Nasional, pendidikan adalah usaha sadar dan terencana untuk mewujudkan suasana belajar dan proses pembelajaran agar peserta didik secara aktif mengembangkan potensi dirinya untuk memiliki kekuatan spiritual keagamaan, pengendalian diri, kepribadian, kecerdasan, akhlak mulia, serta keterampilan yang diperlukan dirinya, masyarakat, bangsa, dan negara. ${ }^{1}$

Tujuan pendidikan dapat tercapai sesuai dengan yang diamanatkan oleh Undang-Undang Republik Indonesia Nomor 20 tahun 2003 tentang Sistem Pendidikan Nasional bahwa; Tujuan pendidikan nasional adalah untuk mengembangkan potensi peserta didik agar menjadi manusia yang beriman dan bertakwa kepada Tuhan Yang Maha Esa, berakhlak mulia, sehat berilmu, cakap, kreatif mandiri, dan menjadi warga Negara yang demokratis serta bertanggung jawab. ${ }^{2}$

Peningkatan mutu pendidikan akan tercapai apabila pembelajaran yang diselenggarakan di kelas benar-benar berjalan efektif dan berguna untuk mencapai kemampuan pengetahuan, sikap dan keterampilan yang diharapkan. Proses pembelajaran pada dasarnya merupakan inti dari proses pendidikan secara keseluruhan, di antaranya guru dan dosen merupakan salah satu faktor yang penting dalam menentukan berhasilnya proses belajar mengajar di dalam kelas. Oleh karena itu guru dan dosen dituntut untuk meningkatkan peran dan kompetensinya.

Guru dan dosen memiliki peranan sangat penting dalam membentuk perilaku belajar peserta didik. Untuk itu menciptakan lingkungan belajar yang efektif dan mampu mengelola kelas harus dipahami oleh guru. Kelas merupakan lingkungan belajar serta merupakan suatu aspek dari lingkungan sekolah yang perlu diorganisir. Lingkungan ini perlu diatur dan diawasi agar kegiatan-kegiatan belajar terarah kepada tujuan-tujuan pendidikan. Lingkungan yang baik bersifat menantang dan merangsang peserta didik untuk belajar, memberikan rasa aman dan kepuasan dalam mencapai hasil belajar yang diharapkan. Untuk menciptakan dan mewujudkan suasana kelas yang efektif, seorang guru dan dosen harus memahami dan mengetahui manajemen kelas.

Manajemen kelas adalah usaha yang diarahkan oleh guru untuk mewujudkan suasana belajar mengajar yang efektif dan menyenangkan serta dapat memotivasi peserta didik untuk belajar dengan baik sesuai dengan kemampuan. Menurut Alam S, manajemen kelas adalah rentetan kegiatan guru untuk menumbuhkan dan mempertahankan organisasi kelas yang efektif, yaitu meliputi: tujuan pengajaran, pengaturan 
waktu, pengaturan ruang dan peralatan, dan pengelompokan peserta didik dalam belajar. ${ }^{3}$

Guru dan dosen yang kompeten akan lebih mampu menciptakan lingkungan belajar yang efektif dan akan lebih mampu mengelola kelasnya sehingga perilaku belajar peserta didik berada pada tingkat yang optimal. Dalam proses belajar diperlukan perilaku belajar yang sesuai dengan tujuan pendidikan, dimana dengan perilaku belajar tersebut tujuan pendidikan dapat tercapai secara efektif dan efesien. Perilaku belajar sering juga disebut dengan kebiasaan belajar yang merupakan dimensi belajar yang dilakukan individu secara berulang-ulang sehingga menjadi otomatis dan spon$\tan { }^{4}$

Berdasarkan hasil observasi selama proses pembelajaran terhadap mahasiswa Jurusan Manajemen Pendidikan Islam Fakultas Tarbiyah dan Keguruan UIN Alauddin ditemukan terdapat mahasiswa yang tidak mengerjakan tugas yang diberikan pada pertemuan sebelumnya, tidak membawa bahan dan materi perkuliahan, diam dan tidak berpartisipasi dalam mengerjakan tugas kelompok.

Berdasarkan penjelasan di atas maka peneliti akan mengkaji secara ilmiah tentang Pengaruh Implementasi Manajemen Kelas terhadap Perilaku Belajar Mahasiswa Pada Jurusan Manajemen Pendidikan Islam Fakultas Tarbiyah dan Keguruan UIN Alauddin.

Berdasarkan latar belakang di atas, maka penulis merumuskan masalah dalam penelitian ini sebagai berikut: Adakah pengaruh implementasi manajemen kelas terhadap perilaku belajar mahasiswa pada Jurusan Manajemen Pendidikan Islam Fakultas Tarbiyah dan Keguruan UIN Alauddin?

\section{KAJIAN TEORI}

\section{Manajemen Kelas}

\section{Definisi Manajemen Kelas}

Manajemen kelas terdiri dari dua kata, yaitu manajemen dan kelas. Manajemen merupakan rangkaian usaha untuk mencapai tujuan yang telah ditetapkan dengan memanfaatkan orang lain, sedangkan yang dimaksud dengan kelas adalah suatu kelompok orang yang melakukan kegiatan belajar bersama sesuai dengan tujuan yang telah ditetapkan, dalam kelas tersebut, guru berperan sebagai manajer utama dalam merencanakan, mengorganisasikan, mengaktualisasikan, dan melaksanankan pengawasan atau supervisi kelas. ${ }^{5}$

Menurut konsepsi lama, manajemen kelas adalah sebagai upaya untuk mempertahankan ketertiban kelas. Sementara itu menurut konsepsi modern, manajemen kelas adalah proses seleksi yang menggunakan alat yang tepat terhadap problem dan situasi manajemen kelas. ${ }^{6}$

Menurut Direktorat Jenderal Pemerintah Umum dan Otonomi Daerah (Dirjen POUD) dan Diretorat Jenderal Pendidikan Dasar dan Menengah (Dirjen Dikdasmen), manajemen kelas merupakan usaha sadar untuk mengatur kegiatan proses belajar 
mengajar secara sistimatis. Usaha sadar itu mengarah pada penyiapan bahan belajar, penyiapan sarana dan alat peraga, pengaturan ruang belajar, mewujudkan situasi/kondisi proses belajar mengajar dan pengaturan waktu sehingga pembelajaran berjalan dengan baik dan tujuan kurikuler dapat tercapai. ${ }^{7}$

Berdasarkan berbagai uraian yang telah dikemukakan oleh para ahli, dapat disimpulkan bahwa manajemen kelas adalah usaha sadar untuk merencanakan, mengorganisasikan, mengaktualisasikan, serta melaksanakan pengawasan terhadap program dan kegiatan yang ada di kelas sehingga proses belajar mengajar dapat berlangsung secara kondusif, efektif, dan efisien.

\section{Tujuan Manajemen Kelas}

Dalam proses manajemen kelas keberhasilannya dapat dilihat dari tujuan apa yang ingin dicapainya, oleh karena itu guru harus menetapkan tujuan apa yang hendak dicapai dengan kegiatan manajemen kelas yang dilakukannya. Secara umum, manajemen kelas bertujuan untuk menciptakan suasana kelas yang nyaman sebagai tempat berlangsungnya kegiatan belajar mengajar atau pembelajaran. Dengan demikian, kegiatan tersebut akan dapat berjalan efektif dan terarah sehingga tujuan pembelajaran yang telah ditetapkan dapat tercapai. ${ }^{8}$

Menurut Sudirman dkk., tujuan manajemen kelas adalah menyediakan fasilias dari bermacam-macam kegiatan belajar peserta didik dalam lingkungan sosial, emosional, dan intelektual dalam kelas. Fasilitas yang disediakan itu memungkinkan peserta didik belajar dan bekerja, terciptanya suasana sosial yang memberi kepuasan, suasana disiplin, perkembangan intelektual, emosional, dan sikap serta apresiasi. ${ }^{9}$

Tujuan manajemen kelas menurut Direktorat Jenderal Pemerintah Umum dan Otonomi Daerah dan Diretorat Jenderal Pendidikan Dasar dan Menengah sebagaimana dikutip oleh Tim Dosen Administrasi Pendidikan Universitas Pendidikan Indonesia, sebagai berikut; 10

1. Mewujudkan situasi dan kondisi kelas, baik sebagai lingkungan belajar maupun sebagai kelompok belajar, yang memungkinkan peserta didik untuk mengembangkan kemampuan semaksimal mungkin.

2. Menghilangkan berbagai hambatan yang dapat menghalangi terwujudnya interaksi pembelajaran.

3. Menyediakan dan mengatur fasilitas serta perabot belajar yang mendukung adan memungkinkan peserta didik belajar sesuai dengan lingkungan sosial, emosional dan intelektual peserta didik dalam kelas.

4. Membina dan membimbing peserta didik sesuai dengan latar belakang sosial, ekonomi, budaya serta sifat-sifat individualnya.

Sedangkan secara lebih khusus Syaiful Bahri Djamarah yang dikutip oleh Novan Ardi Wiyani, mengungkapkan tujuan manajemen kelas sebagai berikut:11

1. Untuk peserta didik

a. Mendorong peserta didik mengembangkan tanggung jawab individu terhadap tingkah lakunya dan kebutuhan untuk mengontrol diri.

b. Membantu peserta didik mengetahui perilaku yang sesuai dengan tata tertib 
kelas dan memahami jika teguran guru merupakan suatu peringatan dan bukan kemarahan.

c. Membangkitkan rasa tanggung jawab untuk melibatkan diri dalam tugas dan pada kegiatan yang diadakan.

2. Untuk guru

a. Mengembangkan pemahaman dalam penyajian pelajaran dengan pembukaan yang lancar dan kecepatan yang tepat.

b. Menyadari kebutuhan peserta didik dan memiliki kemampuan dalam memberi petunjuk secara jelas kepada peserta didik.

c. Mempelajari bagaimana merespons secara efektif terhadap tingkah laku peserta didik yang mengganggu.

d. Memiliki strategi remedial yang lebih komprehensif yang dapat digunakan dalam hubungannya dengan masalah perilaku peserta didik yang muncul di dalam kelas.

Berdasarkan uraian di atas dapat disimpulkan bahwa tujuan manajemen kelas adalah untuk menciptakan kondisi suatu kelas menjadi lingkungan belajar yang kondusif, efektif dan menyenangkan, sehingga tujuan pembelajaran dapat tercapai dengan optimal.

\section{Kegiatan Utama dalam Manajemen Kelas}

Kegiatan manajemen kelas meliputi dua kegiatan yang secara garis besar terdiri dari: 12

1. Menata Ruang Kelas dan Perlengkapannya

Mengatur lingkungan fisik bagi pengajaran merupakan titik mula yang logis untuk pengelolaan ruang kelas, hal ini merupakan sebuah tugas yang dihadapi semua guru sebelum sekolah mulai. Lebih mudah merencanakan aspek pengelolaan ruang kelas lainnya setelah mengetahui bagaimana unsur-unsur fisik dari ruang kelas akan diatur. Ada empat kunci penataan ruangan yang baik, yaitu:

2. Menjadikan wilayah berlalulintas tinggi bebas dari kemacetan

Wilayah-wilayah dimana banyak peserta didik berkumpul dan wilayah yang selalu digunakan dapat menjadi tempat bagi distraksi dan kekacauan. Wilayah dengan lalu lintas tinggi meliputi wilayah kerja kelompok, tempat sampah, wilayah penyimpanan bahan ajar, stasiun komputer, meja tulis peserta didik dan guru. Wilayah ini sebaiknya dipisahkan dalam jarak yang luas satu sama lain, miliki ruang yang luas, dan mudah dicapai.

3. Peserta didik dapat dipantau dengan mudah oleh guru

Keberhasilan guru dalam memantau akan bergantung pada kemampuan guru melihat seluruh peserta didik sepanjang waktu. Oleh karena itu, pastikan terdapat jarak pandang yang jelas di antara wilayah-wilayah pembelajaran, meja tulis anda, meja tulus peserta didik, dan seluruh wilayah kerja peserta didik. Perhatikanlah terutama penempatan lemari buku, lemari arsip, dan barang-barang perabotan dan perlengkapan lainnya yang dapat menghalangi pandangan anda.

4. Menjaga material pengajaran yang sering digunakan dan perlengkapan para pe- 
serta didik mudah diakses

Dalam hal ini tidak hanya mengurangi waktu yang dihabiskan untuk mempersiapkannya dan membersihkannya, itu juga membantu menghindari pelambatan dan penundaan yang menghambat dalam peroses belajar mengajar. Jika guru atau peserta didik harus berhenti untuk menempatkan material dan perlengkapan yang dibutuhkan, guru beresiko kehilangan perhatian dan keterlibatan peserta didik serta waktu pembelajaran dan peroses belajar mengajar.

5. Peserta didik dapat dengan mudah melihat presentasi dan tampilan seisi kelas

Ketika merencanakan posisi guru dan peserta didik dalam presentasi dan diskusi yang melibatkan seluruh kelas, pastikan bahwa pengaturan tempat duduk akan memungkinkan para peserta didik melihat layar OHP atau papan tulis tanpa harus memindahkan kursi mereka, memutar meja tulis mereka, atau memiringkan leher mereka.

6. Pengelolaan Ruang Kelas yang Efektif

Ruang kelas yang efektif memiliki pola dan kebiasaan yang berlaku yang menjadikan interaksi dan pergerakan mudah diorganisasikan dan dilaksanakan. Ruang kelas yang dikelolah secara efektif adalah ruang kelas yang berlangsung dengan lancar, dengan sedikit sekali kebingungan dan keterhambatan, dan memaksimalkan kesempatan pembelajaran peserta didik.

7. Pengelolaan pekerjaan peserta didik

Memiliki prosedur untuk mengelolah pekerjaan peserta didik dapat membatu guru menciptakan sebuah dasar terdokumentasi yang adil untuk penilaian peserta didik dan memungkinkan umpan balik berkala kepada para peserta didik. Prosedur tersebut juga membuat para peserta didik dapat menerapkan kemampuan dan tanggung jawab organisasi personal.

8. Pengelolaan kegiatan pembelajaran

Ruang kelas merupakan lingkungan yang kompleks. Banyak kejadian bisa terjadi dalam satu waktu sekaligus. Seseorang tidak bisa selalu memprediksi dengan pasti apa yang akan terjadi selanjutnya, maka dari itu kegiatan pembelajaran harus dikelolah dengan baik agar apa yang menjadi tujuan pembelajaran dapat tercapai dengan baik.

9. Mengelolah perilaku bermasalah peserta didik

Perilaku bermasalah peserta didik harus ditangani dengan segera untuk mencegah perilaku tersebut terus berkembang dan menyebar. Perilaku tersebut sebaiknya ditangani secara langsung tetapi tanpa reaksi yang berlebihan. Adapun strategi pengelolaan perilaku bermasalah peserta didik, sebagai berikut: ${ }^{13}$

a. Intervensi kecil dapat dilakukan dengan cara-cara berikut; 1) Penggunaan isyarat non verbal, 2) Teruskan kegiatan yang sedang berlangsung, 3) Gunakan kedekatan, 4) Gunakan kelompok focus, 5) Arahkan kembali perilaku, 6) Memberikan instruksi yang dibutuhkan, 7) Berlakukan penghentian sejenak, dan 8) Berikan sebuah pilihan pada peserta didik

b. Intervensi sedang dapat dilakukan dengan cara-cara berikut; 1) Menahan sebuah 
hak istimewa atau kegiatan yang diharapkan, 2) Mengisolasi atau memindahkan peserta didik, 3) Berikan penahanan, 4) Laporkan ke kantor sekolah

c. Intervensi yang lebih besar dapat dilakukan dengan cara-cara berikut; 1) Gunakan pemecahan masalah, 2) Gunakan strategi saatnya berfikir, 3) Berunding dengan orang tua, 4) Buatlah sebuah kontrak individual dengan peserta didik

Berdasarkan uraian di atas, dapat disimpulkan bahwa kegiatan manajemen kelas secara umum ada dua yaitu, kegiatan pencegahan dan korektif. Pelaksanaan kegiatan manajemen kelas mencakup seluruh aspek dan sumber daya yang ada di dalam kelas untuk mendukung kegiatan pembelajaran. Dalam pelaksanaan kegiatan manajemen kelas guru dituntut untuk mengetahui dan memahami komponen-komponen keterampilan manajemen kelas sebagaimana yang telah dijelaskan di atas.

\section{Perilaku Belajar Siswa}

\section{Pengertian Perilaku Belajar}

Secara teoritis belajar dapat diartikan sebagai perubahan tingkah laku, namun tidak semua perubahan tingkah laku organisme dapat dianggap belajar. Perubahan yang timbul karena proses belajar sudah tentu memiliki ciri-ciri perwujudan yng khas dan setiap perilaku belajar selalu ditandai oleh ciri-ciri perubahan yang spesifik. ${ }^{14}$

Hamalik menyajikan dua definisi yang umum tentang belajar, yaitu: ${ }^{15}$

1. Belajar adalah modifikasi atau memperteguh kelakuan melalui pengalaman (learning is defined as the modification or strengthening if behavior throught experiencing);

2. Belajar adalah suatu proses perubahan tingkah laku individu melalui interaksi dengan lingkungan.

Belajar adalah kegiatan berproses dan merupakan unsur yang sangat fundamental dalam penyelenggaraan jenis dan jenjang pendidikan, hal ini berarti keberhasilan pencapaian tujuan pendidikan sangat tergantung pada keberhasilan proses belajar siswa di sekolah dan lingkungan sekitarnya. ${ }^{16}$ Sedangkan menurut Musman belajar adalah proses perubahan tingkah laku yang relatif tetap, dalam proses ini perubahan tidak terjadi sekaligus tetapi terjadi secara bertahap tergantng pada faktorfaktor pendukung belajar yang mempengaruhi siswa. ${ }^{17}$

Perilaku belajar sering juga disebut dengan kebiasaan belajar yang merupakan dimensi belajar yang dilakukan individu secara berulang-ulang sehingga menjadi otomatis dan spontan. ${ }^{18}$

Perilaku belajar yang baik maka akan diperoleh pemahaman yang maksimal terhadap pelajaran dan begitupun sebaliknya dengan perilaku belajar yang buruk, maka pemahaman terhadap pelajaran pun tidak akan maksimal. ${ }^{19}$

Dari beberapa pendapat di atas, dapat disimpulkan bahwa perilaku belajar adalah suatu aktivitas belajar yang menghasilkan perubahan-perubahan pengetahuan, pemahaman, keterampilan, dan nilai sikap.

Adapun ciri-ciri perubahan khas yang menjadi karakteristik perilaku belajar yang penting adalah: 20

1. Perubahan internal dalam arti bukan pengalaman atau praktik yang dilakukan 
dengan sengaja dan disadari, atau dengan kata lain bukan kebetulan.

2. Perubahan positif dan aktif dalam arti baik, bermanfaat, serta sesuai dengan harapan.

3. Perubahan efektif dan fungsional dalam arti perubahan tersebut membawa pengaruh, makna, dan manfaat tertentu bagi siswa.

Dari beberapa pendapat di atas, dapat disimpulkan bahwa ciri-ciri perilaku belajar adalah adanya perubahan pada kebiasaan, tingkat kemampuan, keterampilan atau perubahan yang terjadi pada siswa secara menetap.

\section{METODE PENELITIAN}

\section{Pendekatan dan Jenis Penelitian}

Pendekatan yang digunakan peneliti adalah pendekatan kuantitatif. Penelitian kuantitatif adalah jenis penelitian yang berupa angka-angka dan analisis menggunakan statistik. ${ }^{21}$ Penelitian yang digunakan yaitu Ex Post Facto dengan jenis penelitian penelitian deskriptif korelasional. Nana Sudjana dan Ibrahim menjelaskan mengenai pengertian dari metode penelitian deskriptif korelasi yaitu studi korelasi mempelajari hubungan dua variabel atau lebih, yakni sejauh mana variasi dalam satu variabel berhubungan dengan variasi dalam variabel lain. ${ }^{22}$

\section{Populasi dan sampel}

Populasi yang dimaksud dalam penelitian ini adalah seluruh mahasiswa Jurusan Manajemen Pendidikan Islam Falultas Tarbiyah dan Keguruan UIN Alauddin. Sementara sampel dalam penelitian ini berjumlah 31 orang.

\section{Definisi Operasional Variabel}

\section{Variabel X: Manajemen Kelas}

Manajemen kelas yang dimaksud peneliti adalah usaha yang diarahkan oleh dosen untuk mewujudkan suasan belajar mengajar yang efektif dan menyenangkan serta dapat memotivasi mahasiswa untuk belajar dengan baik sesuai dengan kemampuan yang dimilikinya.

\section{Variabel Y: Perilaku belajar}

Perilaku belajar yang dimaksud peneliti adalah suatu aktivitas belajar yang menghasilkan perubahan-perubahan pengetahuan, pemahaman, keterampilan, dan nilai sikap akibat dari adanya rangsangan dalam diri mahasiswa sehinggga menyebabkan terjadinya perubahan pada diri atau perubahan-perubahan setelah mahasiswa mengalami proses belajar, adapun aspek dari perilaku belajar yang dapat diukur adalah kedisiplinan, kebiasaan, keterampilan, keaktifan dan tingkat kemampuan yang diukur menggunakan angket dengan skala psikologi.

\section{Metode pengumpulan data}

Metode pengumpulan data yang dilakukan dalam penelitian ini adalah skala. 
Skala pengukuran merupakan kesempatan yang digunakan sebagai acuan untuk menentukan panjang pendeknya interval yang ada dalam alat ukur, sehingga alat ukur tersebut bila digunakan dalam pengukuran akan menghasilkan data kuantitatif. 23

Skala yang digunakan adalah skala likert, bertujuan untuk mengukur sikap, pendapat, dan persepsi seseorang atau sekelompok orang tentang fenomena sosial. Dengan skala likert, maka variabel yang akan diukur dijabarkan menjadi indikator variabel. Kemuadian indikator tersebut dijadikan sebagai tolak untuk menyusun item-item instrumen yang dapat berupa pernyataan atau pertanyaan. Jawaban setiap item instrumen yang menggunakan skala likert mempunyai gradasi dari sangat positif sampai sangat negatif, yang dapat berupa selalu, sering, kadang-kadang atau tidak pernah. ${ }^{24}$

\section{Instrumen Penelitian}

Instrumen penelitian adalah alat atau fasilitas yang digunakan oleh peneliti dalam mengumpulkan data agar pekerjaannya lebih mudah dan hasilnya lebih baik, dalam arti lebih cermat, lengkap, dan sistematis sehingga lebih mudah diolah. ${ }^{25}$

Dengan demikian, instrumen harus relevan dengan masalah dan aspek yang akan diteliti, agar supaya memperoleh data yang akurat. Adapun instrumen penelitian yang digunakan peneliti dalam penelitian ini adalah skala psikologi. Skala psikologi merupakan teknik pengumpulan data yang menggunakan skala sebagai alat ukur psikologi. 26

Skala yang digunakan adalah skala likert, bertujuan untuk mengukur sikap, pendapat, dan persepsi seseorang atau sekelompok orang tentang fenomena sosial. Dengan skala likert, maka variabel yang akan diukur dijabarkan menjadi indikator variabel. Kemuadian indikator tersebut dijadikan sebagai tolak untuk menyusun item-item instrumen yang dapat berupa pernyataan atau pertanyaan. Jawaban setiap item instrumen yang menggunakan skala likert mempunyai gradasi dari sangat positif sampai sangat negatif, yang dapat berupa selalu, sering, kadang-kadang atau tidak pernah. ${ }^{27}$

Skala manajemen kelas disusun berdasarkan teori Novan Ardy Wiyani dengan aspek-aspek sebagai berikut:

1. Menciptakan iklim belajar yang tepat

2. Mengatur ruang belajar

3. Mengelolah interaksi kegiatan belajar mengajar

Sedangkan skala perilaku belajar, disusun berdasarkan pendapat dari Muhibbin Syah yang bertujuan untuk mengetahui perilaku belajar siswa. ${ }^{28}$ Adapun aspek-aspeknya adalah sebagai berikut:

1. Kedisiplinan

2. Keterampilan

3. Keaktifan

4. Tingkat kemampuan

\section{Teknik Pengolahan dan Analisis Data}

Pada tahap analisis data yang didasarkan data sampel, dianalisis dengan menggunakan teknik analisis statistik deskriptif dan teknik analisis statistik inferensial. Be- 
berapa uji yang dilakukan pada penelitian ini adalah; 1) Uji normalitas, 2) Uji Linearitas, dan 3) Pengujian Hipotesis.

\section{HASIL DAN PEMBAHASAN}

\section{Hasil Penelitian}

Hasil uji statistik inferensial untuk mengetahui pengaruh implementasi manajemen kelas terhadap perilaku belajar peserta mahasiswa dapat dilihat pada uraian berikut ini.

1. Pearson Product Moment (Uji-r)

$$
\begin{aligned}
r_{x y} & =\frac{\sum x y}{\sqrt{\left(\sum x^{2}\right)\left(\Sigma y^{2}\right)}} \\
& =\frac{-97}{\sqrt{1265 \times 415}} \\
& =\frac{-97}{724,29} \\
& =-\mathbf{0 , 1 3 3}
\end{aligned}
$$

Berdasarkan hasil uji $\mathrm{r}$ di atas, diperoleh $r_{\text {hitung }}-0,133$ dengan taraf signifikan $5 \%$ uji dua pihak $\mathrm{dk}=\mathrm{n}-2=29$ diperoleh $r_{\text {tabel }} 0,367$, jadi $r_{\text {hitung }} 0,133<r_{\text {tabel }} 0,367$. Dari hasil perhitungan dapat diketahui bahwa terdapat pengaruh sebesar 0,67 antara implementasi manajemen kelas dengan perilaku belajar mahasiswa.

Untuk melihat pengaruh antara variabel $\mathrm{X}$ terhadap $\mathrm{Y}$ digunakan statistik regresi linier sederhana. Pengaruh implementasi manajemen kelas terhadap perilaku belajar mahasiswa dapat dilihat pada tabel berikut.

2. Analisis Regresi Sederhana

$$
\begin{aligned}
\mathrm{Y} & =\mathrm{a}+\mathrm{bX} \\
\mathrm{a} & =\frac{\left(\sum Y\right)\left(\sum X^{2}\right)-\left(\sum X\right)\left(\sum X Y\right)}{n \sum X^{2}-\left(\sum X\right)^{2}} \\
& =\frac{(2563,91)(1265,4759)-(2126)(493,511)}{(31)(1265,4759)-(2126)^{2}} \\
& =\frac{3244566-1049204}{39229,75-4519876} \\
& =\frac{2195362}{-4480646} \\
& =-0,5 \\
\mathrm{~b} & =\frac{n \sum X Y-\left(\sum X\right)\left(\sum Y\right)}{n \sum X^{2}-\left(\sum X\right)^{2}} \\
& =\frac{(31)(493,511)-(2126)(2563,91)}{(31)(1265,4759)-(2126)^{2}} \\
& =\frac{15298,84-5450873}{39229,75-4519876} \\
& =\frac{-5435574}{-4480646} \\
= & 1,21
\end{aligned}
$$


Jika $X=31$, maka $Y=-0,5+1,21(31)$

$$
=37,07
$$

3. Uji Signifikansi (Uji t)

a. Untuk regresi, kesalahan bakunyan dirumuskan:

$$
\begin{aligned}
S e & =\sqrt{\frac{y^{2}-\left(a \cdot \sum y\right)-\left(b \cdot \sum x y\right)}{n-2}} \\
& =\sqrt{\frac{413,2562-(-0,5 \times 2563,91)-(1,21 \times 493,511)}{31-2}} \\
& =\sqrt{\frac{(413,2562-(-1281,96))-597,1483}{29}} \\
& =\sqrt{\frac{1695-597,1483}{29}} \\
& =\sqrt{37,86} \\
& =6,15
\end{aligned}
$$

b. Untuk regresi $b$ (penduga $b$ ) kesalahan baku akan dirumuskan :

$$
\begin{aligned}
& S b=\frac{S e}{\sqrt{\sum x^{2}-\frac{\left(\sum x\right)^{2}}{n}}} \\
& =\frac{6,15}{\sqrt{1265,4759-\frac{(2126)^{2}}{31}}} \\
& =\frac{6,15}{\sqrt{1265,4759-\frac{4519876}{31}}} \\
& =\frac{6,15}{\sqrt{1265,4759-145802,5}} \\
& =\frac{6,15}{-144537} \\
& =-4,25
\end{aligned}
$$

c. Menguji Hipotesis

4. Menentukan formulasi hipotesis

Ho: $\beta \mathrm{o}=\longrightarrow \mathrm{\rho o}=0$

Ha : $\beta \neq \beta$ o

5. Menentukan taraf nyata ( $\alpha$ ) dan nilai $t_{\text {tabel }}$

$\alpha=5 \%=0,05 \rightarrow \alpha / 2=0,025$

$d b=n-2=31-2=29$

$t_{\text {tabel }}=t_{0,025(29)}=2,045$

6. Menetukan nilai uji statistik 


$$
\begin{aligned}
t= & \frac{b-\beta 0}{s b} \\
& =\frac{1,21-0}{-4,25} \\
& =-0,28
\end{aligned}
$$

Karena $t_{\text {hitung }}=-0,28 \leq t_{0,025(29)}=2,045$, maka $H_{O}$ ditolak. Berdasarkan hasil tersebut, dapat disimpulkan bahwa implementasi manajemen kelas berpengaruh terhadap perilaku belajar mahasiswa Jurusan Manajemen Pendidikan Islam Fakultas Tarbiyah dan Keguruan UIN Alauddin Makassar.

\section{Pembahasan}

Hasil uji signifikansi regresi linear sederhana menunjukkan bahwa implementasi manajemen kelas berpengaruh terhadap perilaku belajar mahasiswa. Implementasi manajemen kelas yang mempengaruhi perilaku belajar mahasiswa dalam penelitian ini dilihat dari aspek-aspek sebagai berikut.

Menciptakan iklim belajar mengajar yang tepat. Seorang dosen harus mampu menciptakan iklim belajar mengajar yang tepat untuk mewujudkan suasana kelas yang kondusif dan menyenangkan dan dapat memotivasi mahasiswa untuk dapat belajar dengan baik sesuai dengan perkembangan kemampuannya.

Mengatur ruang belajar. Ruang belajar merupakan tempat dimana mahasiswa menghabiskan waktu untuk belajar, maka dari itu ruang belajar dalam hal ini ruang kelas perlu diatur sedemikian rupa sehingga tercipta kondisi kelas yang menyenangkan serta dapat memunculkan semangat serta keinginan untuk belajar dengan baik.

Mengelolah interaksi belajar mengajar. Dalam proses pembelajaran, dosen dan mahasiswa harus aktif. Untuk menciptakan proses pembelajaran yang efektif, dosen harus menguasai dan mempraktekkan keterampilan dasar mengajar.

Ketiga aspek tersebut di atas sesuai dengan pendapat Rusman yang mengatakan bahwa, salah satu faktor yang mempengaruhi perilaku belajar peserta didik yaitu faktor ekternal. Faktor eksternal tersebut meliputi faktor lingkungan dan faktor instrumental, dimana faktor lingkungan meliputi; lingkungan fisik dan sosial, sementara lingkungan instrumental meliputi; kurikulum, sarana dan guru. dengan demikian dapat disimpulkan bahwa semakin baik implementasi manajemen kelas, maka akan memberikan pengaruh yang baik pula terhadap perilaku belajar peserta didik.

\section{KESIMPULAN DAN SARAN}

Berdasarkan uji hipotesis dimana $t_{\text {hitung }} \geq t_{\text {tabel }}=-0,28 \geq 2,045$, hal tersebut menunjukkan bahwa terdapat pengaruh yang signifikansi antara implementasi manajemen kelas terhadap perilaku belajar mahasiswa Jurusan Manajemen Pendidikan Islam Fakultas Tarbiyah dan Keguruan UIN Alauddin Makassar.

Sehubungan dengan hasil penelitian yang telah dikemukakan di atas dan berbagai keterbatasan yang dimiliki penulis dalam penelitian ini, serta implikasinya dalam upaya memberikan motivasi, semangat, dan perhatian yang serius terhadap dosen, 
mahasiswa, maka saran yang dapat dikemukakan dari hasil penelitian ini adalah sebagai berikut:

1. Bagi Dosen dalam proses pembelajaran, sebaiknya memahami implementasi manajemen kelas melalui pembelajaran otodidak dan banyak mencari konsep baru mengenai manajemen kelas, agar tercipta pembelajaran yang kondusif, efisien dan efektif sesuai dengan tujuan yang diharapkan.

2. Bagi Mahasiswa; pelaksanaan manajemen kelas yang baik yang dilaksanakan dosen dalam pembelajaran akan mempengaruhi sikap dan perilaku mahasiswa. Hasil penelitan ini diharapkan agar mahasiswa dapat lebih memahami perilaku belajar dan melaksanakan bentuk betuk perilaku belajar tersebut selama menjadi mahasiswa.

3. Bagi Peneliti Selanjutnya; penelitian ini masih memiliki beberapa kelemahan di antarannya adalah jumlah sampel yang masih terbatas pada suatu jurusan dan instrumen penelitian yang masih memerlukan validasi sehingga data yang diperoleh benar benar menggambarkan kondisi populasi yang sesungguhnya.

\section{CATATAN AKHIR:}

1. Hasbullah, Dasar-dasar Ilmu Pendidikan, (Jakarta: Rajawali Pers, 2012), h. 4.

2. Hasbullah, Dasar-dasar Ilmu Pendidikan, h. 307

3. Tim Dosen Administrasi Pendidikan Univesitas Pendidikan Indonesia, Manajemen Pendidikan (Bandung: Alfabeta, 2011) h. 107

4. Hanifah, "Pengaruh Perilaku Belajar terhadap Prestasi Akademik Mahasiswa Akuntansi", (Media Riset Akntansi, Auditing dan Informasi Vol 1, No.3 Desember 2001) h. 67

5. Euis Karwati dan Donni Juni Priansa, Manajemen Kelas, h. 5.

6. Afrizah, Manajemen Kelas (Pekanbaru: Kreasi Edukasi, 2014), h. 8. http://www.fush.uinsuska.ca.id.html

7. Tim Dosen Administrasi Pendidikan Univesitas Pendidikan Indonesia, Manajemen Pendidikan, h. 106

8. Novan Ardy Wiyani, Manajemen Kelas: Teori dan Aplikasi untuk Menciptakan Kelas yang kondusif, h. 64 .

9. Syaiful Bahri Djamarah, Strategi Belajar Mengajar (Cet. III; Jakarta: PT. Rineka Cipta, 2006), h. 178.

10. Tim Dosen Administrasi Pendidikan Univesitas Pendidikan Indonesia, Manajemen Pendidikan, h. 107

11. Novan Ardy Wiyani, Manajemen Kelas: Teori dan Aplikasi untuk Menciptakan Kelas yang kondusif, h. 64 .

12. Carolyn M. Evertson dan Edmund T. Emmer, Classroom Management for Elementary Scool Teacher, terj. Arif Rahman, Manajemen Kelas untuk Guru Sekolah Dasar, Edisi Kedelapan (Jakarta: Prenadamedia Group, 2015), h. 2.

13. Carolyn M. Evertson dan Edmund T. Emmer, Classroom Management for Elementary Scool Teacher, terj. Arif Rahman, Manajemen Kelas untuk Guru Sekolah Dasar, h. 233.

14. Muhibbin Syah. Psikologi belajar. h.117

15. Asep Jihad. Evaluasi Pembelajaran (Yogyakarta: Multi Pressindo, 2012) h. 2

16. Asep Jihad. Evaluasi Pembelajaran. h.1

17. Nurul H dkk, “Analisis Pengaruh Perilaku Belajar dan Intelektualitas terhadap Hasil Ujian 
Akhir Nasional", (Jurnal Dinamika Ekonomi \& Bisnis, Vol. 4 No. 1 Maret 2007) h. 40

18. Hanifah, "Pengaruh Perilaku Belajar terhadap Prestasi Akademik Mahasiswa Akuntansi", (Media Riset Akntansi, Auditing dan Informasi Vol 1, No.3 Desember 2001) h. 67

19. Masyitah As Sahara. "Pengaruh Perilaku belajar, kecerdasan Emosional, kecerdasan intelektual, kecerdasan spritual, dan kecerdasan sosial terhadap pemahaman akuntasi". (eJurnal Ilmiah Program Studi Akuntansi Universitas Maritim Raja Ali Haji, Tanjungpinang, Vol 3, No.1, 2014) h.4

20. Asep Jihad. Evaluasi Pembelajaran .h. 6

21. Sugiyono, Metode Penelitian Pendidikan Pendekatan Kuatitatif, Kualitatif, dan RED, (Cet. 20; Bandung; Alfabeta, 2014), h. 13

22. Nana Sudjana dan Ibrahim, Penelitian dan Penilaian Pendidikan, (Cet. IX; Bandung: Sinar Baru Algesindo, 2009), h. 77.

23. Sugiyono, Metode Penelitian Kuantitatif Kualitatif dan RED, h. 133

24. Sugiyono, Metode Penelitian Kuantitatif Kualitatif dan RED, h. 134

25. Suharsimi Arikunto. Prosedur Penelitian Suatu Pendekatan Praktik. (Cet 15; Jakarta: Rineka Cipta, 2013), h. 203

26. Saifuddin Azwar, Penyusunan Skala Psikologi. (Yogyakarta: Pustaka Pelajar), h. 6

27. Sugiyono, Metode Penelitian Kuantitatif Kualitatif dan R\&D, h. 134

28. Muhibbin Syah, Psikologi Belajar. hal. 120

\section{DAFTAR PUSTAKA:}

Afrizah. Manajemen Kelas. Pekanbaru: Kreasi Edukasi, 2014. http://www.fush.uin-suska.ca.id.html.

Aswar, Saifuddin, Penyusunan Skala Psikologi. Yogyakarta: Pustaka Pelajar, 2015.

Arikunto, Suharsimi. Pengelolaan Kelas dan Peserta didik Sebuah Pendeekatan Evaluati., Jakarta: PT. Haji Mas Agung, 1996.

Barnawi dan M. Arifin. Manajemen Sarana \& Prasarana Sekolah, Yogyakarta: Ar-Ruzz Media, 2012.

Ekosiswoyo, Rasdi dan Maman Rachman. Manajemen Kelas. Semarang: IKIP Semarang Pres2, 2000.

Evertson, Carolyn M. dan Edmund T. Emmer. Classroom Management for Elementary Scool Teacher. terj. Arif Rahman, Manajemen Kelas untuk Guru Sekolah Dasar. Edisi Kedelapan. Jakarta: Prenadamedia Group, 2015.Djamarah, Syaiful Bahri. Strategi Belajar Mengajar. Cet. III; Jakarta: PT. Rineka Cipta, 2006.

Departemen Agama RI. Al-Qur'an dan Terjemahnya, Bandung: CV Penerbit Jumanatul Ali, 2004.

Djamarah, Syaiful Bahri dan Aswan Zain. Strategi Pembelajaran. Jakarta: Rineka Cipta, 2006.

Djamarah, Syaiful Bahri. Psikologi Belajar. Bandung: Rineka Cipta, 1996.

Hasbullah. Dasar-dasar Ilmu Pendidikan. Jakarta: Rajawali Pers, 2012.

Karwati, Euis dan Donni Juni Priansa. Manajemen Kelas. Bandung: Alfabeta, 2014.

Mulyasa, E. Menjadi Guru Profesional: Menciptakan Pembelajaran Kreatif dan Menyenangkan. Bandung, PT. Rosdakarya, 2009.

Purwanto. Evaluasi Hasil Belajar. Yogyakarta: Pustaka Pelajar, 2014.

Purwanto, M. Ngalim. Prinsip-Prinsip dan Teknik Evaluasi Pengajaran. Bandung: PT. Remaja Rosdakarya, 1994.

Rusman. Belajar dan Pembelajaran Berbasis Komputer Mengembangkan Profesionalisme Guru Abad 21, Bandung: Alfabeta, 2012. 
Saud, Udin Syaefuddin. Pengembangan Profesi Guru, Bandung: Alfabeta, 2011.

Slameto. Belajar dan Faktor-Faktor yang Mempengaruhinya. Jakarta: Rineka Cipta, 2010.

Sudijono, Anas. Pengantar Evaluasi Pendidikan. Jakarta: Rajawali Pers, 2013.

Sugiyono. Metode Penelitian Pendidikan: Pendekatan Kuantitatif, Kualitatif, dan RED. Bandung: Alfabeta, 2015.

Sukardi, Metodologi Penelitian Pendidikan Kompetensi dan Praktiknya. Jakarta: PT. Bumi Aksara, 2008.

Suryabrata, Sumadi. Psikologi Pendidikan. Jakarta: Rajawali Pers, 2006.

Sutriman. Media dan Model-Model Pembelajaran Inovatif, Yogyakarta: Graha Ilmu, 2013.

Syah, Muhibbin. Psikologi Belajar. Bandung: PT. Remaja Rosda Karya, 2008.

Tim Dosen Administrasi Pendidikan Univesitas Pendidikan Indonesia. Manajemen Pendidika., Bandung: Alfabeta, 2011.

Wibowo, Agus. Manajemen Pendidikan Karakter di Sekolah, Yogyakarta: Pustaka Pelajar, 2013.

Wiyani, Novan Ardy. Manajemen Kelas: Teori dan Aplikasi untuk Menciptakan Kelas yang kondusif. Yogyakarta: Ar-Ruzz Media, 2013.

Sugiyono, Statistika untuk Penelitian (Bandung: Alfabeta, 2015) 